\title{
The Chronic Administration of Persian Herbal Formulas Psycodigest Induced The Antidepressant- Like Effect in a Chronic Unpredictable Mild Stress (CUMS) Mouse Model
}

Research Article

Keywords:

Posted Date: February 19th, 2021

DOI: https://doi.org/10.21203/rs.3.rs-158432/v2

License: (9) (i) This work is licensed under a Creative Commons Attribution 4.0 International License. Read Full License 


\section{Abstract}

The authors have requested that this preprint be withdrawn due to erroneous posting.

\section{Full Text}

The authors have withdrawn this preprint from Research Square. 